Colonies since its establishment in 1946. In these and in many other spheres he has maintained the high standards of conscientiousness, sagacity and humanity for which he is so well known.

\section{Prof. I. Chester Jones}

IAN Chapster Jones, who has been elected to succeed Prof. L. E. S. Eastham in the chair of zoology at Sheffield, obtained a first-class degree in the honours school of zoology at Liverpool in 1938 and received the degree of Ph.D. in 1941. His war service was in the Army, from which he emerged with the rank of major in 1946 and returned to Liverpool as assistant lecturer. Apart from two years at Harvard in the tenure of a Commonwealth Fund Fellowship, he has remained at Liverpool as lecturer and senior lecturer. Dr. Chester Jones's research since the Second World War has lain wholly within the general field of comparative endocrinology which he has done much to create and of which he is one of the most distinguished exponents. His monograph on the adrenal cortex (1957) is the first serious attempt at a general synthesis of what is known of that puzzling gland in every class of vertebrate. In 1954 he organized an extremely successful symposium at Liverpool on comparative endocrinology, the report on which, edited by him and Dr. Eckstein, has since appeared as the fourth and fifth memoirs of the Society for Endocrinology. He has earned for himself at Liverpool an enviable reputation by his ability both to train and to inspire young post. graduate students. At Sheffield his opportunities will be greater, and it is to be assumed that the grantsin-aid which have supported his work so far will be continued on a scale appropriate to the new circumstances. A well-known text-book on vertebrate zoology opens with a paragraph on the need for generality: and it is just this quality which has been most conspicuously lacking in the treatment of endocrinology until recently. Dr. Chester Jones's high reputation rests, in part, on his early recognition of this need and on his sustained effort to meet it.

\section{Secretaryship of the International Commission on Zoological Nomenclature}

Mr. Francis Hemming, who has been honorary secretary to the International Commission on Zoological Nomenclature since 1936, is to retire on account of ill-health. He has also been advised that he ought not to incur the physical strain involved in completing the arrangements for the Colloquium on Zoological Nomenclature which is to be held in London next July immediately before the meeting of the Fifteenth International Congress of Zoology.

With the consent of Sir William Pugh, director of the Geological Survey, London, and with the approval of the Department of Scientific and Indus. trial Research and of the Treasury, Mr. R. V. Melville, a senior member of the palæontological staff of the Survey, has been released for a period of one year to become assistant secretary to, and director of, the Commission. In addition, Mr. Melville has been appointed assistant manager to the Trust. His first duty will be to obtain suitable accommodation for the office of the Commission (which hitherto has been housed rent-free in Mr. Hemming's private residence) and to complete the arrangements for the meeting of the Colloquium on Zoological Nomenclature. Mr. Hemming has consented to see through the press the edition of the "Official Lists" and
"Official Indexes" now in preparation and, in addition, to prepare the "Opinions" required to give effect to the decisions already taken by the Commission in a number of cases. Mr. Hemming has also agreed for the time being to retain the position of managing director and secretary of the Trust. In view of the close association between the work of the Section on Nomenclature of the International Congress of Zoology and the work of the Colloquium on Zoological Nomenclature, Sir Gavin de Beer, as president of the forthcoming Congress, has invited Mr. Melville to act as recorder for the Section in succession to Mr. Hemming.

\section{Working Party on Higher Education to visit East Africa}

AfTER consultation with the Governors of Kenya, Tanganyika and Uganda and the British Resident of Zanzibar, the Secretary of State for the Colonies, Mr. Alan Lennox-Boyd, has appointed a Working Party on Higher Education which is to visit East Africa in mid-July. The chairman will be Dr. J. F. Lockwood, vice-chancellor of the University of London, and the members will be: Dame Lillian Penson (professor of modern history, University of London), Sir David Keir (master, Balliol College, Oxford), Prof. E. Giffen (Queen Mary College, University of London) and Prof. L. E. S. Eastham (University of Sheffield). The secretary will be $\mathrm{Mr}$. I. C. M. Maxwell. The terms of reference are as follows : (1) To examine and advise on the proposals for the creation of new institutions of higher education in East Africa and to advise on their desirability and scope, and on the timing of their establishment. (2) To examine and advise on the pattern of future development of higher education in East Africa; and in this connexion to examine the desirability and practicability of carrying out any such development within the scope of a single university or university college of East Africa of which all colleges territorially situated would be constituent units. (3) To examine and advise on the additional facilities, if any, for higher technological and professional training, which are required in East Africa.

\section{Translations of Russian Scientific Literature}

IN replying to a question on the translation of Russian scientific and technical literature in the House of Commons on April 29, Mr. H. Nicholls, Parliamentary Secretary to the Ministry of Works, representing the Lord President of the Council, said that the Department of Scientific and Industrial Research is giving considerable thought to this difficult problem and is urgently considering ways and means of expanding the number and availability of the translations. The Lord President did not accept the implication in the question that it is a waste of time for research scientists to learn Russian, but he fully recognized the great importance of the matter and would do everything possible to accelerate the service requested. Mr. Nicholls reiterated that normally the best translations of scientific and technical papers are produced by working scientists with a knowledge of Russian. The Lord President had no knowledge of detailed arrangements in the United States but was aware that some Russian scientific and technical periodicals were being translated by commercial agencies there. There appears to be no advantage in separate translations of the same documents into English being made on both sides of the Atlantic. Mr. Nicholls agreed that we should 